\title{
A Utilitarian Argument for Vegetarianism
}

\author{
Nicholas Dixon \\ Alma College
}

\begin{abstract}
Editors' note: The original of this paper by Professor Dixon, the response by Professor Wellington, and the reply by Dixon were presented at the Central Division meetings of the Society for the Study of Ethics and Animals, held in Chicago, Illinois, April, 1995.
\end{abstract}

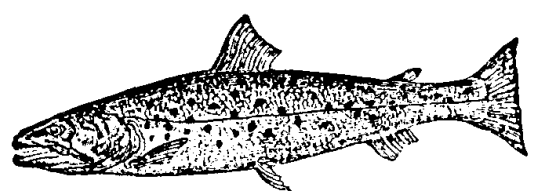

\section{Types of Opposition to Vegetarianism}

Although supporters of vegetarianism (and animals' interests in general) come in many varieties, we may distinguish two groups. First, utilitarians such as Singer base their argument on the suffering that factory farming causes to nonhumans and the absence of comparable benefits to humans. ${ }^{1}$ Second, the animal rights view, as expressed by Regan, extends Kant's respect for persons principle to include nonhumans and argues that meat eating wrongly treats nonhumans merely as means. ${ }^{2}$

Similarly, I find it useful to distinguish two types of defense of meat eating. My division is based on how each group responds to Singer's demand that we extend the equal consideration of interests principle ${ }^{3}$ to include nonhumans and to his parallel between speciesism and, on the other hand, racism and sexism. Some grant Singer's premise that nonhumans do deserve equal consideration of interests, but they argue either that animals actually benefit from being raised on farms or that their suffering is outweighed by human gains. Others, paralleling Regan's rights approach, reject utilitarian calculations of interests. However, they argue, in direct opposition to Regan,

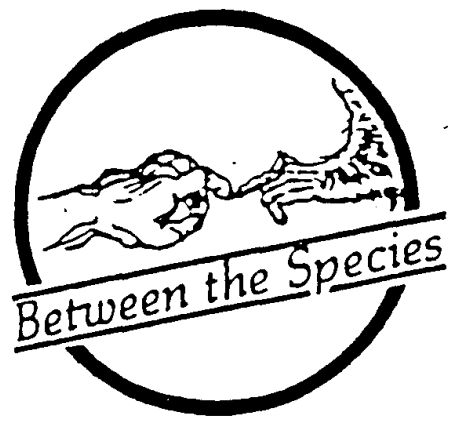

that animals' interests are qualitatively less important than those of humans or even that animals' interests are not morally significant at all. While we should not gratuitously cause them suffering, we may use them as we wish in order to benefit ourselves. In contrast to utilitarian defenders of meat eating, I call this second group "human supremacists."

My goal in this paper is to argue that neither type of defense of meat eating is successful against Singer's utilitarian argument for vegetarianism. Instead of attempting a comprehensive response to all defenses that fall into these two categories, I will focus on what I consider to be the most powerful, representative ones. I have confined myself to Singer's argument for the strategic reason that it requires only that we extend moral concern to all sentient beings. Sceptics are more likely to grant this premise than they are to accept Regan's persuasively argued but more controversial view that all animals have an intrinsic value that may not be sacrificed in the course of utilitarian calculations. ${ }^{4}$

\section{Utilitarian Defenses of Meat Eating}

In this section, I am interested in those who try to justify meat eating on Singer's own utilitarian terms. They agree, that is, that to attempt to justify meat eating by simply asserting that humans are superior to nonhumans is speciesist and that it is incumbent on them to explain

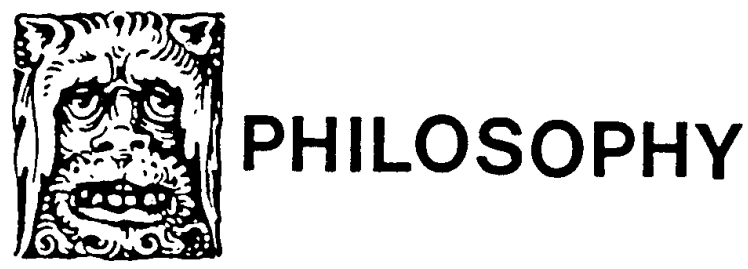


how human gains from meat eating outweigh nonhuman suffering. I will focus mainly on R.G. Frey's justification of meat eating in his book, Rights, Killing, and Suffering. ${ }^{5}$ Frey takes Singer's challenge seriously and gives a careful, detailed response.

Frey defends the strategy of the "concerned individual," who continues to eat meat but tries to reform farming techniques in order to eliminate cruelty to farm animals. He argues that Singer's demand for the end of factory farming is based on the implausible "single experience" view of suffering: meat eating is wrong if it causes any suffering at all to farm animals. Frey proposes that we adopt instead the "miserable life" view of suffering, according to which we may be justified in causing animals some pain in order to raise them for food, as long as we ensure that their lives are on balance more pleasant than painful. He points out that the "single experience" view of suffering would almost certainly have the absurd consequence that raising human children would also be wrong, since it would be practically impossible to eliminate all suffering from their lives. ${ }^{6}$

Frey is correct when he argues that the "miserable life" view of suffering is superior to the "single experience" view. However, his argument neglects a third option that is more salutary than either of the ones he considers. I will call this third option the "minimal suffering" view. Granted, the "single experience" view is too stringent, but his "miserable life" view has the opposite fault of being too lenient. It is itself vulnerable to a reductio: it would justify even the gratuitous infliction of suffering on our children, as long as the suffering is just barely outweighed by the pleasure they experience. Far more plausible is my "minimal suffering" view, which permits the infliction of suffering only when doing so prevents even greater suffering or when it is a deserved punishment for past behavior. Abusing children (while carefully ensuring that their overall happiness outweighs their suffering) is repugnant, because it does not serve any legitimate punitive purpose or prevent even greater long-term suffering, either for our children or ourselves. Similarly, the suffering caused to animals when we raise them for meat is justified only if they deserve it (which is clearly not the case) or if it helps to prevent even greater suffering. Consequently, the burden is on Frey to show what the benefits of continuing to raise animals for meat are and how they outweigh the suffering caused to animals.
Frey argues that the concerned individual's tactic is sufficiently effective in reducing animals' suffering to justify continuing to raise animals for meat. Throughout his book, Frey takes advantage of a concession that Singer makes: the equal consideration of interests principle does not necessarily condemn all meat farming, since animals raised on free range farms (and, we may suppose, on the kind of reformed farms that Frey proposes) ${ }^{7}$ may avoid much of the suffering for which Singer condemns factory farms. However, Singer questions whether even free range farms would reduce animals' suffering to a level that would be outweighed by humans' gains and whether, even if they did so, they would be economically feasible. ${ }^{8}$ Moreover, he points out that the pertinent issue is whether we may eat today's meat, most of which is raised on factory farms. ${ }^{9}$ In any event, even if Frey were able to show that the concerned individual's tactic and vegetarianism would have equally good consequences for the animals, his argument for continuing to raise animals for meat would still depend on showing that doing so would have better consequences for humans than vegetarianism.

Before we turn to Frey's answer to this challenge, let us examine another utilitarian defense of meat eating that goes even further than Frey's and argues that our practice of raising animals on farms benefits the animals themselves. Farm animals have become domesticated, so the argument goes, and would be unable to survive in nature, were we to set them free. If exposed to life in the wild-bitter winters, savage predators, etc.-farm animals would be likely to die slowly and painfully from starvation, or quickly and savagely at the hands of wolves and bear. As long as we follow Frey's concerned individual's tactic and reform our farming practices to give animals long and peaceful lives, we are actually doing them a favor. A life that is overall pleasurable, even though it might contain some pain, is preferable to no life at all, which is the likely consequence of ending meat farming.

This "animal husbandry" argument can draw support from an unexpected source: J. Baird Callicott's defense of a "land ethic." He criticizes supporters of animal rights for ignoring the vital distinction between wild and domestic animals. ${ }^{10} \mathrm{He}$ argues that none of the likely outcomes of our ceasing to raise animals for meat are favorable to the animals themselves. Unused to fending for themselves in competition with other wild animals, domestic animals are likely to become extinct, and we might consider it more humane simply to allow 
existing farm animals to die peacefully on farms than to put them at the mercy of predators. Callicott comments on the irony of the liberation of domestic animals resulting in their extinction. ${ }^{11}$

I follow Bart Gruzalski in biting the bullet in response to this reductio ad absurdum argument. ${ }^{12}$ The discontinuation of meat farming will likely result in the replacement of domestic by wild animals. But this is an advantage, since it will result in an increase in the total amount of pleasure experienced by nonhuman animals. First, even if the adoption of Frey's concerned individual's tactic makes domestic animals' lives pleasurable, this pleasure will be replaced by that of the additional wild animals that will flourish on the land previously used for grazing on farms. ${ }^{13}$ Second, wild animals live more pleasurable lives than domestic ones. Gruzalski points out that no amount of modification of our current farming practices will eliminate the frustration of animals' natural urges and instincts, in terms of movement, social organization, and diet. Thus, it isn't clear that animals raised in the manner proposed by Frey's "concerned individual" have lives that are on balance pleasurable. In contrast, while wild animals can indeed suffer painful "natural" deaths from predators, these deaths at least avoid the additional terror caused by the unfamiliar environment of the slaughterhouse. And some wild animals die peacefully of old age, thus avoiding any terror at all.

We still need to address another of Callicott's objections, which is also based on the distinction between domestic and wild animals. Arguments (such as Gruzalski's) that claim that meat farming frustrates animals" "natural desires" neglect the fact that "human artifacts" such as domestic animals do not have a nature that can be violated.

It would make almost as much sense to speak of the natural behavior of tables and chairs. ${ }^{14}$

In response, Gruzalski cites experts who believe that

the natural, instinctive urges and behavioral patterns...of... ancestral wild species have been little, if at all, bred out in the process of domestication. ${ }^{15}$

In the face of this stalemate on the nature of domestic animals, we may reasonably err on the side of caution and place the burden of proof on those who would use animals for food. In any event, the animal husbandry argument has been neutralized, since its goal was to show that meat farming is beneficial to animals, and we have seen that the replacement of farm animals by wild animals would create at least as much happiness as is currently experienced by farm animals. ${ }^{16}$ Moreover, even if we concede that domestic animals have no natural instincts that could be violated, our utilitarian approach still favors a world in which wild animals flourish in the place of domestic animals, since animals that both have a nature and live in nature arguably have richer, more fulfilling lives.

Those who go beyond the utilitarian framework used in this paper can further criticize the confinement of animals on meat farms by citing Regan's view that raising animals on farms violates their inherent value, by treating them only as a means. Even though he rejects Singer's and Regan's approach, Callicott himself gives a nonutilitarian reason against factory farming, namely that it involves "the monstrous transformation of living things from an organic to a mechanical mode of being."17

The foregoing discussion suggests that nonhuman animals would be better off if we completely ended meat farming than if we followed the tactic of Frey's concerned individual. Consequently, the justifiability of the concerned individual's tactic hinges on showing that the benefits for humans of continuing to raise animals for meat outweigh its disutility for nonhumans. Let us turn at last to Frey's main argument.

Frey bases his utilitarian defense of meat farming on a detailed conjecture as to the bad economic consequences for humans of its cessation. ${ }^{18}$ Frey predicts a massive loss of income and employment, not only for farmers but also for the vast number of people in meat-related industries. He also includes the loss of pleasure resulting from a decrease in such social activities as restaurant-going and barbecues. Since space does not permit detailed discussion of Frey's specific predictions, I will confine myself to a few general responses.

First, Frey's argument is based on worst-case scenarios which underestimate the new economic and social opportunities that will arise because of the need for enormously greater production of vegetarian food. For instance, the growing popularity of vegetarianism in the United States and, especially, in England has led to a profusion of vegetarian restaurants, and most restaurants now offer vegetarian options. These 
developments indicate that the gloomy predictions that Frey made twelve years ago about the future of the restaurant industry if meat eating were to be abandoned were unfounded. The fact that even MacDonalds has developed a vegetarian burger, and that supermarkets now stock a wide variety of different types of non-meat burgers and hot dogs, undermines Frey's claim that fast food restaurants would collapse and shows that barbecues could continue even if we gave up meat. More generally, Frey's claim that all vegetarian restaurants are alike reflects the common myth that vegetarian cuisine is bland, a charge that is already belied by the imaginative menus available in such restaurants.

Second, even granting that conversion to vegetarianism would cause some economic hardship, and granting Frey's point that this hardship is commensurable with animals' suffering, ${ }^{19}$ economic factors are unlikely to outweigh the physical and mental suffering that would remain for farm animals even if we reformed farming methods. By analogy, even a purely utilitarian approach, which forswears any reference to rights, would certainly not accept the economic arguments that could doubtless have been made in favor of child labor in the 19th. century. The children's suffering outweighs any financial gains that might have arisen from exploiting this source of cheap or free labor.

Third, a consistent utilitarian approach must consider not only the potentially harmful effects for humans of giving up raising animals for meat but also its potential benefits for us. As well as the health benefits arising from giving up meat, we must take into account the fact that, as a far more efficient source of protein than a meat-based diet, a vegetarian diet may help substantially to alleviate the problem of world hunger. ${ }^{20}$ Now, Frey is aware of these arguments based on human welfare, ${ }^{21}$ and, reasonably enough, he decides to focus instead on arguments based on animal welfare, since these arguments bave "recently given the question of vegetarianism a new focus." 22 The problem for Frey is that the alleged harmful effects for humans of vegetarianism play a vital role in his response to the argument for vegetarianism based on animals' suffering. The structure of his argument is that, since the concerned individual's tactic is effective in reducing animals' suffering, the harmful effects for humans of giving up meat farming are sufficient to tilt the utilitarian balance against vegetarianism. Consequently, any beneficial effects of vegetarianism for humans are also directly relevant to Frey's utilitarian defense of meat farming, yet he does not include these effects in his discussion of consequences. Only if he can show that the benefits for humans of meat farming outweigh its disutility for animals and for humans has he successfully responded to Singer's utilitarian argument defended in this paper.

In sum, Frey's argument, even if supplemented by the animal husbandry argument, fails to overcome the utilitarian case against raising animals for meat. Neither his contention that it will sufficiently reduce animals' suffering, nor his argument that it will have better results for humans than vegetarianism, have succeeded in making the case for the concerned individual's strategy. Consequently, the only certainties are that today's meat farming causes the animals considerable suffering and that discontinuing meat farming will end that suffering.

\section{Human Supremacism}

We have seen that meat eating is hard to justify on utilitarian grounds. Once we concede that the moral interests of nonhumans should be given equal weight alongside those of humans in our moral deliberations, human gains from meat eating appear trivial compared to animals' losses. At this point, many defenders of meat eating take a different tack and withdraw their assent from Singer's application of the equal consideration of interests principle to nonhumans. According to this position, which I call "human supremacism," humans' interests should count for more than those of nonhumans, making utilitarian comparisons of human and nonhuman gains and losses inappropriate.

The issue at stake between utilitarian vegetarians such as Singer and, on the other hand, human supremacists is whether the morality of meat eating depends on a quantitative comparison between the gains and losses of humans and animals. Singer believes that it does and argues that giving preference to humans in spite of animals' greater interests is speciesist and, therefore, wrong. Human supremacists, in contrast, claim that a qualitative comparison is also needed. Because humans have greater inherent moral value than nonhumans, human interests should take precedence over those of animals. I devote this section to an examination of one such human supremacist view, that of Carl Cohen, who brazenly embraces the label of speciesist. His paper concerns medical experiments on animals, but I will consider its implications for vegetarianism. ${ }^{23}$ Cohen himself clearly believes that his argument justifies meat eating, since he offers as a 
reductio ad absurdum of arguments against medical research on animals the consequence that meat eating would also be wrong. ${ }^{24}$

Speciesism is not analogous to racism and sexism, Cohen argues, because whereas no morally relevant distinctions exist between the races and sexes, the morally relevant differences between humans and nonhumans are "enormous, and almost universally appreciated." 25 Now, Singer would not deny that humans, because of their greater intelligence, have greater interests than do nonhumans. The equal consideration of interests principle requires not equal treatment but, rather, that like interests be given equal weight. Consequently, in situations in which humans' and nonhumans' interests clash, humans' greater interests will sometimes justify giving them preference. For example, since "[n]ormal adult human beings have mental capacities that will, in certain circumstances, lead them to suffer more than animals would in the same circumstances," 26 we may sometimes be more justified in performing scientific experiments on nonhumans than on humans. Singer opposes meat farming, however, because our benefits are easily outweighed by animals' suffering.

In contrast, Cohen flatly denies that "the pains of all animate beings must be counted equally" 27 and even that nonhumans have any rights at all. On what qualities does Cohen base humans' alleged greater inherent moral value?

Cohen believes that only beings that are capable of both claiming their own and respecting other beings' rights are eligible for having rights:

Humans confront choices that are purely moral; humans-but certainly not dogs or mice-lay down moral laws, for others and for themselves. Human beings are selflegislative, morally auto-nomous...Animals (that is, nonhuman animals, the ordinary sense of that word) lack this capacity for free moral judgment. They are not beings of a kind capable of exercising or responding to moral claims. Animals therefore have no rights... ${ }^{28}$

Cohen does not deny that we do have duties towards nonhumans, even though they have no rights. In particular, we "are at least obliged to act humanely" towards animals, in view of their status as sentient creatures. But these obligations are imperfect, in the sense that no animal has a right to be treated in this way. Cohen does not explain exactly what the extent of our imperfect obligations to animals is. At one point, he refers to the duty not to gratuitously harm sentient creatures. On the interpretation of "gratuitous" that I assume Cohen intends, this would rule out torturing animals for our pleasure but would permit virtually any of the currently common uses of nonhumans, including meat eating and medical experiments. However, defenders of animal rights regard most of these common practices as gratuitous, because the sacrifices imposed on nonhumans are not outweighed by human gains. Consequently, Cohen's view, whatever its other merits, fails to give a clear criterion for determining which uses of nonhumans are justified.

To his credit, Cohen deals directly with the most obvious objection to his account of rights. The objection, the so-called "argument from marginal cases," is that very young, severely retarded, or comatose humans would also fail to qualify if being able to exercise and respond to moral claims is a necessary condition for having rights. ${ }^{29}$ They are not moral agents, since they are unable to reciprocate any moral concern that we show towards them, nor are they able even to understand any moral claims that may be made on their own behalf. But we do regard them as having rights, and we punish people, such as child abusers, who violate these rights. ${ }^{30}$

Cohen's response is that qualification for rights depends upon the "natural moral functions" of the species. Members that, due to youth, birth defects or accidents, do not have these capacities are, as it were, carried through on the coattails of the rest of the species.

The capacity for moral judgment that distinguishes humans from animals is not a test to be administered to human beings one by one... The issue is one of kind..$^{31}$

All nonhuman animals, in contrast, simply lack the capacities that most humans have. The first problem with Cohen's response is that, while it produces the result he desires-humans have rights, and nonhumans don't-it amounts to an assertion rather than an argument. Exactly why should rights be based on the normal capacities of a species rather than on the capacities of each individual member? Second, his view seems to entail an absurd consequence. Suppose that one of the chimpanzees that have been taught sign language develops an ability to understand moral 
arguments, to restrain its behavior in the light of these arguments, and to make moral claims on its own behalf. These abilities would remain far above the "natural moral functions" of chimpanzees as a species. Consequently, according to the view that bases rights upon the normal capacities of the species as a whole, this chimpanzee would have to be denied the status of a right-holder. But this seems arbitrary and unfair.

None of this is to deny that humans' greater capacities sometimes give rise to special moral obligations towards them. For instance, because of their ability to make and respond to moral claims, I am able to make agreements and promises and to enjoy deep, mutually supportive relationships with healthy humans that are difficult or impossible with nonhumans or "marginal" humans. These agreements, promises and relationships make our moral ties to healthy adult humans more extensive and complex than those we have to nonhumans. But this does not preclude nonhumans from having rights, any more than the fact that I have special moral obligations towards some people, such as my friends and family members, precludes strangers from having moral rights that I treat them certain ways. Since I am defending Singer's utilitarian view, my response to Cohen is not intended to show that animals have rights. My point, rather, is that nonhumans have as much claim to having rights as do humans and that the existence of special obligations towards healthy adult humans does not entail human supremacism.

Similarly, I can concede other justified differences between the moral standing of healthy adult humans and nonhumans, without resorting to human supremacism. The view that only self-conscious beings capable of future-oriented desires, especially the desire for continued life, can have a right to life ${ }^{32}$ can be justified on the utilitarian ground that persons' greater mental capacities, including their greater power of anticipation, mean that they would lose more than nonpersons from being killed.

These human capacities that are not shared by nonhumans-e.g., the ability to make and respect moral claims and to form extensive future-oriented desireswill sometimes act as a "tie-breaker" that justifies giving preference to humans-for instance, if we had to choose between feeding humans or a dog in a time of extreme shortage. However, the justification for giving preference to humans has nothing to do with humans' alleged greater inherent moral worth. It is, rather, that giving equal weight to the like interests of humans and nonhumans, an impartial utilitarian calculus requires that we give preference to humans in these rare situations. The moral community is strengthened when, other things being equal, we give priority to beings capable of reciprocating our moral concern. And when either a human or a nonhuman has to suffer physically or die, humans' greater capacity for suffering will usually tilt the utilitarian balance in their favor.

The situation is completely different when we consider the utilities involved in the debate over meat eating. Since we do not need meat to survive, we are not faced with the choice of imposing comparable suffering on either humans or nonhumans, and so humans' greater capacities are irrelevant to the tradeoff of interests involved. As we saw in the previous section, a quantitative comparison of rival interests shows that human gains are insufficient to justify the imposition of suffering on nonhumans. So, the only way to justify continuing to raise animals for food is to abandon the utilitarian approach that gives equal weight to the like interests of humans and nonhumans. But we have just seen that Cohen has failed to give a cogent reason for abandoning the utilitarian approach and regarding human interests as qualitatively more important than those of nonhumans. Consequently, the human supremacist approach fails to dislodge our earlier conclusion that raising animals for food is wrong.

\section{Conclusion: Theory and Practice}

I have argued that the strongest utilitarian defense of raising animals for meat-Frey's-does not work and that the human supremacist attempt to sidestep utilitarian calculations by attributing greater intrinsic moral worth to humans is unfounded. However, even if we accept that the discontinuation of raising animals for meat would have better results than following the concerned individual's tactic, Frey points out that a crucial step remains to be provided before any utilitarian argument can condemn meat eating. This step is showing that the act of becoming a vegetarian and encouraging others to do so will actually help to achieve the goal of the abolition of meat farming and, hence, produce better results than the concerned individual's tactic. Frey argues that the practical impact of any one person's becoming a vegetarian will be negligible, given the vastness of the meat industry in countries like the U.S. ${ }^{33}$ In contrast, political action in order to reform farming practices to reduce animals' suffering is far more likely to produce tangible benefits. 
In response, the private action of becoming a vegetarian in no way precludes political activism of precisely the kind that Frey supports. The only difference is that the activism would aim at the abolition, rather than the reform, of raising animals for meat. Additionally, while my becoming a vegetarian may have negligible effect, Frey dismisses too easily the impact of the combined effect of thousands of people's becoming vegetarians. Given the dramatic increase in vegetarian restaurants and vegetarian options within conventional restaurants in the twelve years since Frey's book appeared, we may plausibly claim that conversion to vegetarianism really has reduced the amount of meat that would otherwise have been produced and consumed. Finally, as vegetarianism becomes more "mainstream," it gains more credibility and power as a political force.

My second response to Frey concerns the morality of eating today's meat, the vast majority of which is raised on the very factory farms that he wants to reform. A great strength of Frey's book is that he gives a detailed and sophisticated discussion of the charges of insincerity and inconsistency that we might level at the concerned individual, who, while campaigning for reform, continues to eat meat raised in a manner that he or she concedes causes unfair suffering to animals. ${ }^{34}$ Frey responds plausibly enough by pointing out that demanding that we have absolutely no contact with a practice that we consider wrong is unduly rigid. For instance, I can quite actively and consistently oppose my country's foreign policies, without leaving the country in order to express the extent of my disapproval. Similarly, argues Frey, as long as the concerned individual actively strives to reform cruel farming practices, the fact that she continues to eat meat is proof of neither insincerity nor inconsistency.

However, continuing to eat meat while striving for reform is different in a crucial respect from Frey's analogies. Remaining in a country and trying to change its policies from within is arguably far more effective than simply leaving the country and having no contact with it. In contrast, continuing to eat meat seems to have no positive impact on the effectiveness of the concerned individual's attempt to end cruel farming practices. On the contrary, a reduction in the demand for meat (which is the likely result of a temporary boycott by concerned individuals) would seem to create economic pressure on the meat industry that is likely to accelerate the desired reforms. Once the reforms have occurred, the concerned individual may then resume eating meat. So even the concerned individual is not justified in eating meat raised on today's factory farms. The concerned individual who continues to eat meat, even though she admits that it was produced in cruel conditions and that her eating meat will in no way enhance her efforts to improve these cruel conditions, seems to be guilty of a lack of integrity.

In conclusion, my utilitarian argument that raising animals for meat is wrong does indeed demand a vegetarian diet. And even if Frey were correct that trying to reform our practice of raising animals for meat would have better consequences than working for its abolition, eating the meat raised on today's factory farms would still not be justified on utilitarian grounds.

I am grateful to an anonymous referee, commentator Alex Wellington, Harlan Miller, and audience members for helpful suggestions.

\section{Notes}

${ }^{1}$ Peter Singer, Animal Liberation, 2nd. edition (New York: New York Review, 1990); and Practical Ethics, 2nd. edition (Cambridge: Cambridge University Press, 1993), ch. 3-5.

${ }^{2}$ Tom Regan, The Case for Animal Rights (Berkeley, CA: University of California Press, 1983).

3 "The essence of the principle of equal consideration of interests is that we give equal weight in our moral deliberations to the like interests of all those affected by our actions." Practical Ethics, p. 21.

${ }^{4}$ Similarly, the fact that I do not discuss arguments for vegetarianism based on a feminist ethic of care is not intended to reflect a negative judgment on these arguments. It reflects only the fact that the purpose of this paper is to respond to objections to the best-known argument for vegetarianism: Singer's utilitarian view.

${ }^{5}$ R. G. Frey, Rights, Killing and Suffering (Oxford: Basil Blackwell, 1983).

${ }^{6}$ Ibid., pp. 174-83.

${ }^{7}$ Frey is not explicit on whether his reformed farms would be considered free range farms or more humane factory farms.

${ }^{8}$ See Singer, Practical Ethics, pp. 64-65.

${ }^{9} \mathrm{Ibid}$. I pursue this theme further in section 4 .

$10 \mathrm{~J}$. Baird Callicott, “Animal Liberation: A Triangular Affair," Eugene C. Hargrove (ed.), The Animal Rights/ 
Envimnmental Ethics Debate (Albany, State University of New York Press, 1992), pp. 52-59.

${ }^{11} \mathrm{Ibid}, \mathrm{p} .54$.

${ }^{12}$ Bart Gruzalski, "The Case Against Raising and Killing Animals for Food," Harlan B. Miller and William H. Williams (eds.), Ethics and Animals (Humana Press, 1983). The section in which he discusses the animal husbandry argument is reprinted in Thomas Mappes and Jane Zembaty (eds.), Social Ethics, 4th Edition (New York: MoGraw-Hill, 1992), pp. 449. 53. Page references are to the reprint.

${ }^{13}$ Gruzalski, "The Case Against Raising and Killing Animals for Food," pp. 450-51.

${ }^{14}$ Callicott, “Animal Liberation: A Triangular Affair," p. 53. See also Frey, Rights, Killing, and Suffering, pp. 185-86, for a similar argument.

15 Gruzalski, "The Case Against Raising and Killing Animals for Food," p.452.

${ }^{16}$ In his more recent article, "Animal Liberation and Environmental Ethics," reprinted in Eugene C. Hargnove (ed.), The Animals Rights/Environmental Ethics Debate: The Environmental Perspective (Albany: State University of New York Press, 1992), Callicott has proposed a partial reconciliation between his view and that of supporters of individual animals' interests, such as Singer and Regan. However, his view on the moral status of so-called domestic farm animals has not changed significantly. Continuing to distinguish them from wild animals, Callicott regards the use of domestic animals for food as unobjectionable, as long as, unlike factory farmers, we do not violate the "kind of evolved and unspoken social contract between man and beast." (Ibid., p. 256)

${ }^{17}$ Callicott, “Animal L iberation: A Triangular Affair,” p. 58.

${ }^{18}$ Frey, Rights, Killing, and Suffering, pp. 197-206.

${ }^{19} \mathrm{Ibid}$., p. 241.

${ }^{20}$ See Gruzaiski, "The Case Against Raising and Killing Animals for Food," p. 451; and Singer, Practical Ethics, p. 220.

${ }^{21}$ Frey, Rights, Killing, and Suffering, pp. 17-20.

${ }^{22}$ Ibid., p. 24.

${ }^{23}$ Carl Cohen, "The Case for the Use of Animals in Biomedical Research," The New England Journal of Medicine, vol. 315 (Oct. 2, 1986). Page references are to its reprint in Mappes and Zembaty, Social Ethics.

${ }^{24}$ Cohen, "The Case for the Use of Animals in Biomedical Research," p. 466.

${ }^{25}$ Ibid., p. 463.
${ }^{26}$ Peter Singer, Practical Ethics, p. 59.

${ }^{27}$ Carl Cohen, "The Case for the Use of Animals in Biomedical Research," p.463.

${ }^{28}$ Ibid., p. 460.

${ }^{29}$ This objection is a variation on an argument given by Singer, Practical Ethics, pp. 67-68, 74-78.

${ }^{30}$ For a discussion of other unsavory consequences of the view that bases moral standing on the ability to reciprocate, see Peter Singer, Ibid., pp. 78-82.

${ }^{31}$ Cohen, "The Case for the Use of Animals in Biomedical Research," p. 461.

${ }^{32}$ See Peter Singer, Practical Ethics, pp. 95-99; and Mary Anne Warren, "Human and Animal Rights Compared," Social Ethics, p. 469.

${ }^{33}$ Frey, Rights, Killing, and Suffering, pp. 206-16.

${ }^{34} \mathrm{Ibid}$. , ch. 18.
Konrad Gessner

Beasts \& Animals

New York: Dover, 1983

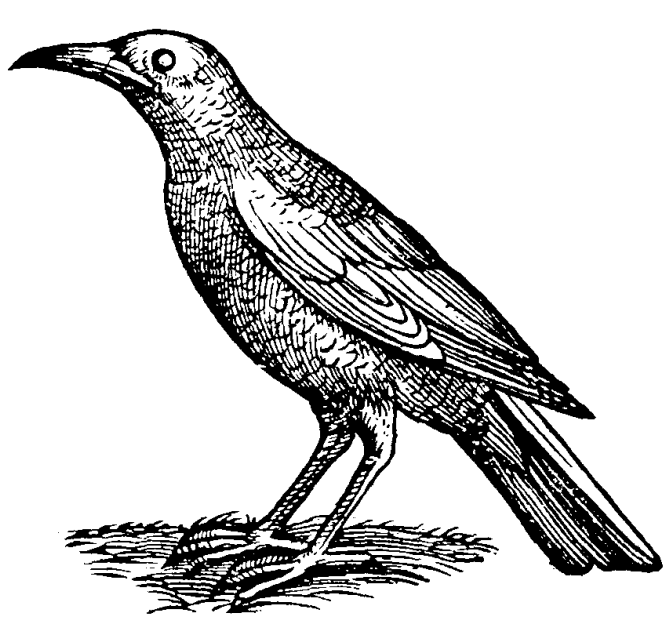

Summer \& Fall 1995 


\section{Response: Feminist Positions on Vegetarianism:
Arguments For and Against and Otherwise ${ }^{1}$

\section{Alex Wellington \\ York University}

I

Nicholas Dixon has organized his paper, "A Utilitarian Argument for Vegetarianism," around the positions for and against vegetarianism that are derived from the two main currents of traditional ethical theoriesutilitarianism and some variant of a rights-based approach. These currents are reflected in the work of Peter Singer and Tom Regan, respectively and are taken up by many others who write in the area. It is easy to understand why, in the context of his project of providing a utilitarian argument for vegetarianism, he chooses to limit the discussion to the two groups he addresses-utilitarianism and "human supremacism." Yet, it leaves out an entire area of recent deliberation and debate concerning the moral imperative of vegetarianism, that which is presented in contemporary ecofeminist thought. This is an area which deserves consideration, and not only for reasons of comprehensiveness, representation and inclusivity. It deserves consideration, also, and perhaps more importantly, because the issues addressed and points made by feminist writers on the topic speak directly to the need to combine "private decision with political action."

I wish to focus instead on a third set of arguments that can provide - on some variants - the basis for

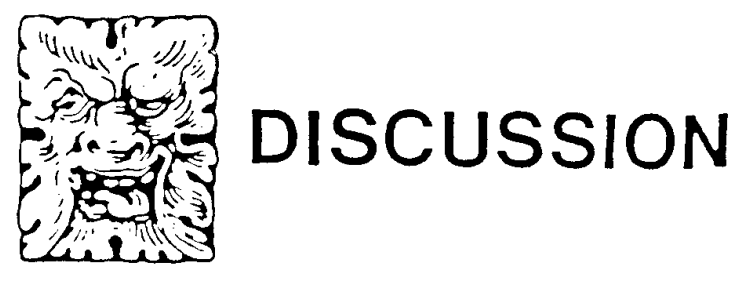

support for vegetarianism as well as a critical perspective on the positions taken by adherents of traditional ethical theories. Feminist approaches to the issue enable one to explore the relationship between theory and practice in our moral lives; indeed, they require one to address the question of connections between theory and practice. Ultimately as with all complex and sophisticated ethical theories, it has to be said that the introduction of feminist theorizing into the topic of vegetarianism does not lead to easy answers or simple remedies. It is both intellectually interesting and practically significant that just as one can find utilitarian arguments both for and against vegetarianism and rights-based arguments both for and against vegetarianism, there are a range of possible feminist positions on vegetarianism.

There are many reasons for addressing the topic of vegetarianism from a feminist, or rather from feminist perspectives. ${ }^{3}$ For one thing, a remarkable proportion of the increasing number of vegetarians are women. ${ }^{4}$ The emphasis in much feminist literature in ethics on the connection between life experience and values makes it worth examining the gender dimension of the so-called "vegetarian option." Further, a significant amount of recent writing on vegetarianism, in particular, has been produced by feminists, and there have been several very prominent and influential ecofeminist treatments of the issue which make the case for the necessity of the connection. ${ }^{6}$ Popular literature on animal rights and vegetarianism often seems to assume that there is a simple and easy case to be made for allying feminism with vegetarianism. Carol Adams puts it succinctly and forcefully when she implies that the "values and beliefs imbedded in the choice to eat animals are antithetical to feminism."7

Recent articles, nevertheless, have touched on the tensions within feminist circles about the issue of endorsing vegan, or even vegetarian conferences and events. ${ }^{8}$ Ecofeminists, specifically, contend that "in the case of meat eating, the personal is political"; yet, not all feminists accept this. ${ }^{9}$ Some feminists have even suggested that efforts to endorse vegetarianism are tantamount to cultural imperialism, and have the effect of undermining cultural traditions, in particular those of women of color. ${ }^{10}$ Thus, some feminists are likely to feel a reluctance to advocate vegetarianism for several reasons: in order to avoid the accusation of cultural imperialism, out of deference to cultural traditions, and not wanting to be perceived as 
infringing on women's rights to choose. Some feminist theorists reject the claims of animal rights theory on other theoretical grounds.

It might be helpful at this point to distinguish two disparate approaches to feminist ethics: one based on a "care ethic" and one based on an "anti-domination ethic." "The former is derived from, and developed out of the work of psychologist Carol Gilligan, whose book In A Different Voice is widely read and whose ideas have become extremely influential. The latter can be found in the work of feminist theorists such as Carol Adams, Karen Warren, Lori Gruen and Kathryn Paxton George, among others. Simply put, the care ethic emphasizes the importance of relationships and emotional connections between beings, and the antidomination ethic advocates the "elimination of any and all factors that contribute to the continued and systematic domination or subordination of women." 12

What I hope to show in this paper is that there is no neat and tidy relation between a particular approach to ethics and a stance on the moral imperative of vegetarianism. Some people think that a care ethic will support, or even require vegetarianism, others do not. And similarly, some people think that an antidomination ethic will support, or even require vegetarianism, but others do not. The importance of an exploration of feminist perspectives on vegetarianism, I argue, does not reside in whether or not the approach will produce the "right answer." The importance lies instead in the approach taken to moral reasoning.

I will first discuss the claims made by Nell Noddings on behalf of a variant of care ethic and the positions she takes on human obligations towards animals derived from that ethic. She finds that the development of her ethical perspective does not dovetail with the approach taken by ecofeminists and others. Next, I will examine the positions advocated by adherents of variants of an anti-domination ethic. I will first address those theorists who argue for an integral connection between feminism and vegetarianism. I will then look at the analysis presented by Kathryn Paxton George, who takes an antidomination approach but explicitly critiques the arguments of traditional ethical theory in favour of the "vegan ideal." It is clearly worth exploring why some feminists think vegetarianism is morally obligatory and others don't. It is also worth speculating on the implications of their approaches to moral reasoning, on their views about how moral thinking and feeling should proceed.
II

The care ethic is premised a "mode of thinking that is contextual and narrative rather than formal and abstract." ${ }^{3}$ Gilligan proposes that there is a different moral voice, one which tends to be articulated by women and tends to be empirically associated with women. This different moral voice is concerned with care and responsibility rather than with the focus of the dominant moral voice-rights and justice. The dominant moral voice, Gilligan claims, tends to be articulated by men and tends to be empirically associated with men. The ethic of care is thus contrasted with the ethic of rights and justice. In passing, I would like to point out that Gilligan sometimes writes as if one could simply combine utilitarianism and a deontological or rights-based approach to ethics in one position. Other authors, such as Josephine Donovan, who write about "animal rights theory" tend to use this term to cover both utilitarian and rights-based approaches. Needless to say, moral philosophers would resist this lumping and find it unhelpful at best.

Nell Noddings' book Caring: A Feminine Approach to Ethics and Moral Education contains a chapter titled "Caring for Animals, Plants, Things and Ideas." In a passage in that chapter, Noddings makes clear that her "caring" ethic extends only to humans and that her approach to ethics would not result in a judgmental stance against raising animals for food, eating meat or other human uses of animals (sealing, hunting, fishing etc.). She says positive things about keeping pets, in part because of the benefits to humans in so doing. Similarly, spiders, toads and snakes are welcome in the garden due to their usefulness. As for rats, she says she would not torture a rat, and she would hesitate to use poisons on one, but she "would shoot it cleanly if the opportunity arose." 14 Thus, her approach is really quite anthropocentric, a fact which she does not try to deny. Noddings, ultimately, does not accept the interpretation of speciesism found in animal rights theory. She says instead that "[i]t is not "speciesism" to respond differently to different species if the very form of response is species specific." 15

It is necessary to set her remarks in context in order to understand why she takes the position she does. For Noddings, primary moral obligation is located in the domain of human life. The ethical impulse or attitude, she says, is grounded in the caring relation. Caring, in turn, depends upon past experience and conscious 
choice. ${ }^{16}$ Caring is anchored in recognition of relations. Furthermore, our obligation to summon the caring attitude is limited by the possibility of reciprocity. ${ }^{17}$ Obligation, then, can only arise on encounter. ${ }^{18}$ As responsiveness or perceived responsiveness increases in the potential to be cared-for being, then so does caring.

What this means for animals is that affection for animals varies greatly across persons. Some people will have had past experiences-encounters with certain animals and they will choose to undertake a commitment to that being. Such is the reason that Noddings herself perceives an obligation to her family pet, a cat who appears expectantly, stretches its neck, and vocalizes its need. ${ }^{19}$ In response, Noddings feels obligated to that particular animal, and perhaps to others of its kind she encounters. But the obligation does not extend any further, and certainly not to animals in general. For Noddings, one cannot be obligated to the entire class of animals. ${ }^{20}$

Of course, other people will not have had past experiences or encounters with animals, nor will they choose to undertake any commitments to animals. In that case, they can hardly be said to have an obligation to any particular beings, on Noddings' account. They can be expected to avoid inflicting pain, since the one thing that Noddings' approach does require is that we must not inflict pain without justification. One must act to "prevent pain to consciousness, even the nonreflective consciousness of animals." 21 According to Noddings, when the form of response of the being in question permits detection of pain, then we as caregivers are obligated to relieve it. Noddings' version of a care ethic, then, seems to provide a rationale for a minimal obligation to refrain from inflicting pain upon animals, although even that may be qualified. ${ }^{22}$ It does not give rise to further obligations to promote the welfare of animals, except insofar as particular caregivers choose to undertake a commitment to care for particular animals. It would not lead to judgmental stances prohibiting meat eating or the raising of animals for food or other reasons.

I do not want to dwell on a discussion of the "care ethic," since I think that most arguments for vegetarianism that rest upon a feminist ethic depend upon the anti-domination version of feminist ethics. In addition, as I have already mentioned, at least one proponent of the care ethic version of feminist ethicsnamely Nell Noddings-explicitly rejects the idea that the care ethic entails support for vegetarianism.
Donovan actually tries to combine elements of both the care ethic and the anti-domination ethic approaches to feminist ethics. I will now go on to discuss the antidomination versions of feminist ethics.

\section{III}

In an article entitled "Animal Rights and Feminist Theory," Josephine Donovan sets out the case for a feminist or feminine ethic to address the issue of the ethical treatment of animals. She claims that it is necessary to ground an ethic of concern for animals in what she calls "an emotional and spiritual conversation with nonhuman life-forms." She finds both utilitarianism and rights theories to be inadequate for this purpose, primarily due to the insistence of male moral philosophers that their positions are rooted in reason and not emotion.

Donovan quotes Peter Singer's preface to Animal Liberation in which he recounts an anecdote about a visit to the home of a woman who claimed to love animals but who ate meat. He writes: "....certainly she was keen to talk about animals. 'I do love animals', she began... and she was off. She paused while refreshments were served, took a ham sandwich, and then asked us what pets we had." 23 Donovan says that Singer's point "is not only to condemn the woman's hypocrisy in claiming to love animals while she was eating meat but also to dissociate himself from a sentimentalist approach to animal welfare." 24 Singer then goes on to profess that he and his wife were not particularly interested in, nor fond of animals, that they did not 'love' animals. He says that the "portrayal of those who protest against cruelty to animals as sentimental, emotional 'animal lovers' [has meant] excluding the entire issue... from serious political and moral discussion." 25 Donovan takes Singer to be assuming that associating the cause of animal rights "with 'womanish' sentiment is to trivialize it." 26

Donovan goes on to propose that women animal rights theorists-here she includes people like Mary Midgley (author of Animals and Why They Matter) and Constantia Salamone (an activist) have been able to develop theories which acknowledge and emphasize the importance of emotional bonding with animals. Midgley, for example, talks about the social and emotional complexity of animals and says: "[w]hat makes our fellow beings entitled to basic consideration is surely not intellectual capacity but emotional 
fellowship."27 Salamone and other activists adopt a more explicitly feminist stance and condemn the "rationalist, masculinist bias of current animal rights theory," according to Donovan. ${ }^{28}$

There are at least two ways in which emotion and emotional fellowship between humans and nonhuman animals could be relevant to the discussion of the ethical treatment of animals. One way in which it could be relevant is in providing reasons to treat animals with kinship. Thus, the biological affinity between humans and other animals could be seen to be at least partial justification for treating animals with equal concern and respect. If this is the intended interpretation, then the feminist position would simply echo the utilitarian position first formulated by Jeremy Bentham, who said " $\mathrm{t}]$ he question is not, Can they reason? nor, Can they talk? but, Can they suffer?"29

I would argue that this is not the import of feminist approaches presented by Donovan and others. Recognition of sentience or the capacity for suffering or enjoyment does not distinguish feminist approaches from utilitarian approaches. The issue that arises from the application of feminism to the question of the ethical treatment of animals is the role of emotion in the process of ethical reasoning. I take Donovan's critical point to be that a feminist ethic for the treatment of animals is one that emerges out of "women's relational culture of caring and attentive love." 30 She implies, then, that moral reasoning should attend to this culture and should incorporate a sensitivity to the affective dimension of our (meaning us humans) relations with animals as well as with each other. ${ }^{31}$

Carol Adams uses the phrase "traffic in animals" as a parallel to the term "traffic in women" to suggest the parallels. Lori Gruen emphasizes the social construction of the connection between women and animals, a connection created by patriarchy as a means of oppression. She says that "ecofeminists are committed to a reexamination and rejection of all forms of domination." 32 She refers to the work of Karen Warren during the elaboration of her anti-domination ethical perspective. Karen Warren, in "The Power and Promise of Ecological Feminism," presents a critique of the role of conceptual frameworks in the logic of domination, a logic which has justified both the domination of nature and women by men.

Warren argues that there are several significant features of oppressive conceptual frameworks including value dualisms and logic of domination. ${ }^{33}$ Value dualisms are disjunctive pairs which are seen as oppositional and exclusive and which place higher status, prestige and value on one disjunct rather than another. Examples include: mind/body, reason/emotion, male/female. A logic of domination is a structure of argumentation which leads to a justification of subordination. The justification rests on the grounds of characteristics-for example, rationality-which allegedly the dominant (e.g., men) have and the subordinate (e.g., women and nonhuman animals) supposedly lack. ${ }^{34}$

Warren argues that ecofeminism "involves an ethical shift from granting moral consideration to nonhumans exclusively on the grounds of some similarity they share with humans (e.g., rationality, interests, moral agency, sentiency, right-holder status)." 35 Warren implies that the shift is toward an approach which provides a contextual account, one which has several significant features: it "makes a central place for values of care, love, friendship, trust and appropriate reciprocity" and it "involves a reconception of what it means to be human, and in what human ethical behavior consists." 36 As with Donovan, it seems as if elements from the care ethic and the anti-domination ethic are being merged and combined.

\section{IV}

There is yet another feminist perspective on vegetarianism and in particular, on the vegan ideal, which needs to be brought into the discussion, and that perspective can be found in the work of Kathryn Paxton George. George has taken a critical stance on the assumption that there is a simple connection between a feminist approach rooted in concern for social justice and the universalist prescription in favor of ethical veganism based on traditional moral theory. George has asked the question "Should feminists be vegetarians?" and her answer seems to be "Not necessarily." She argues that the vegan ideal is actually discriminatory because the arguments for it "presuppose a 'male physiological norm' that gives a privileged position to adult, middleclass males living in industrialized countries." 37

George's concern is that people who are not adult, middle-class males living in industrialized countries cannot be expected to adopt vegetarian and vegan diets for a whole series of reasons-having to do with ecology, economy and nutrition. These people would thus have to be excused from the duty to attain the virtue 
associated with ethical lifestyles. As George puts it: "[i]f women, and infants, and children, and the elderly, and those who live almost everywhere else besides western societies are routinely excused for doing what would normally be considered wrong, in practice this relegates them to a moral underclass of beings who, because of their natures or cultures, are not capable of being fully moral. ${ }^{\text {38 }}$ This leads her to suggest that the moral tradition which has this implication is one which is designed to serve only the most privileged class of humans.

The point that vegetarianism can be more easily realized by persons in industrialized countries has been made elsewhere. As Beardsworth and Keil put it: "[t]he conditions in which contemporary voluntary vegetarianism can flourish are located not only in a cultural climate of nutritional pluralism. They also rest on the economic foundations of an affluent, consumer-oriented economy which can draw upon a vast array of food items, freed by the channels of international trade from the narrow limits of locality, climate and season." ${ }^{19}$ George adds to this point a concern with the gender dimensions of the vegan ideal.

The claim that George makes, based on these points, is that the traditional arguments for animal rights and animal welfare or liberation are tainted by bias. I do not want to enter into the debate concerning the accuracy of the nutritional literature on which George bases her critique-some of that debate can be found in Gary Varner's article "In Defence of the Vegan Ideal." 40 Suffice it to say that George thinks her analysis is well grounded in contemporary scientific studies and analysis, but her critics disagree.

I do want to suggest that George's critique has interesting implications for a utilitarian defense of vegetarianism. The critique would have some relevance for a reassessment of rights-based theories, but it is less clear what the implications would be. Certainly, consequentialist utilitarianism has to take seriously the potential consequences of advocacy of universal vegetarianism and veganism. If there is sufficient substance to the claim that the vegan ideal is discriminatory due to the ecological, economic and nutritional factors outlined by George, then that has to be taken into account. Utilitarians need to consider the potential effects of their prescriptions on everyone concerned. It does seem somewhat arbitrary to limit the evaluation to only Western, industrialized societies. There has been an ongoing critique of environmental ethics generally, for its shortsightedness and ethnocentrism. It seems that George's work, if nothing else, has raised the concern that animal rights theory might have to address a similar critique.

V

Karen Warren's and Lori Gruen's ecofeminist perspectives on ethics would seem to lead to a position on the treatment of animals that converges with Carol Adam's position derived from feminist critical theory and feminist theology. They would all recommend vegetarianism as a feminist statement against patriarchal dominance. Josephine Donovan details the kinds of actions and policies concerning the treatment of animals that she thinks are entailed by the feminist rejection of either/or thinking, or epistemological dualism. She says feminists should reject the following: carnivorism, the killing of animals for clothing, hunting, the trapping of wildlife for fur, factory farming, use of lab animals for testing of beauty and cleaning products, rodeos, and circuses. Feminists must work to abolish the "animalindustrial complex," in other words. ${ }^{41}$ Additionally, feminists must support efforts to replace medical experiments by computer models and tissue culture and support the drastic redesigning of zoos. As she puts it, "[a]ll of these changes must be part of a feminist reconstruction of the world." 42

From the perspective of moral philosophy and the question of the choice of ethical theory, it is significant that the list of recommended actions and policies provided by Peter Singer or Tom Regan or other adherents of either utilitarian or rights-based theories would not differ significantly from that presented by Donovan. Thus, for many proponents of the antidomination ethic the prescriptive import of a feminist approach resembles that of traditional ethical theories, but the crucial difference lies in how one argues for those recommended actions or policies.

\section{Notes}

\footnotetext{
'This paper was initially titled "Feminist Arguments for and against Vegetarianism: Response to Nicholas Dixon's 'A Utilitarian Argument for Vegetarianism'." It was prepared for the Society for the Study of Ethics and Animals sessions held in Chicago, Illinois, on April 27, 1995. I have revised and expanded that original paper.

${ }^{2}$ Nicholas Dixon, in his conclusion, acknowledges that Frey's admonitions to combine private decision with political
} 
action are well taken. In a sense, I see my paper as beginning where his left off. I wanted to explore the implications of feminism for the specific issue and also for moral reasoning in general. I do wish to state, nonetheless, that his paper provides an exemplary illustration of the merits of traditional ethical theorizing. When it is very well done, as his paper certainly is, it is certainly still worth doing.

${ }^{3}$ It has become increasingly clear that it is not really possible to speak of a feminist perspective, or the feminist approach. There are myriad potential variants, or versions, of feminism. Some of these can be grouped in broad clusters, such as "cultural" feminism or "socialist" feminism or "liberal" feminism, but these labels have limited usefulness. Even within these broad clusters, there is as much diversity as there is between and among them.

${ }^{4}$ A Gallup Poll in Britain in 1995 found that the percentage of Britons who are self-defined vegetarians had doubled since 1984 to 4.5 per cent and that "[w]omen were almost twice as likely as men to be vegetarian." The Economist, August 19, 1995, 20. Beardsworth and Keil report that in the 1990 Gallup study, "the combined group of vegetarians plus red meat avoiders was 10.0 per cent, compared with... 4.0 per cent in 1984" (at 255-256). In that same study, 12.8 per cent of female respondents "claimed to eat meat rarely or not at all," whereas the figure for men was 7.1 per cent. Thus, the gender difference has been continuous. See "The Vegetarian Option: Varieties, Conversions, Motives and Careers," by Alan Beardsworth and Teresa Keil, The Sociological Review, 1992, 253-293 at 256. Age plays an important role, since young women are the most likely of all to be vegetarian. One in eight young women in Britain "professes vegetarianism." The Economist, August 19, 1995, 20.

${ }^{5}$ This is the title of an article by Alan Beardsworth and Teresa Keil, supra. It does give the impression that vegetarianism is, in effect, a lifestyle choice. What I want to suggest in this paper is that for many ecofeminists, it is much more than a question of lifestyle choice.

${ }^{6}$ Some recent examples include the following: Carol $\mathbf{J}$. Adams, The Sexual Politics of Meat: A Feminist-Vegetarian Critical Theory, Continuum, 1990. Carol J. Adams and Josephine Donovan, editors, Women and Animals: Feminist Theoretical Explorations, Duke University Press, 1995. Greta Gaard, editor, Ecofeminism: Women, Animals, Nature, Temple University Press, 1993 (the papers by Lori Gruen and Carol J. Adams specifically). See also Carol J. Adams and Marjorie Procter-Smith, "Taking Life or "Taking on Life"?," in Carol J. Adams, editor, Ecofeminism and the Sacred, Continuum, 1993. Michael Allen Fox has written about the influence of feminist thought on his defense of vegetarianism and critique of environmental ethics. See his "Environmental Ethics and the Ideology of Meat Eating," Between the Species: A Journal of Ethics, Volume 9, 1993.
${ }^{7}$ Carol J. Adams, "The Feminist Traffic in Animals," at 196. In Gaard, ed., Ecofeminism, Animals, Nature.

${ }^{8}$ Both Lori Gruen and Carol J. Adams discuss their frustrations when "proposals to make feminist events crueltyfree have been rejected. Both mention an incident involving the June 1990 convention of the National Women's Studies Association, in which "the Coordinating Council rejected the Ecofeminist Task Force recommendation that it "make a strong statement of feminist non-violence, and make NWSA a model of environmental and human behavior by adopting a policy that no animal products... be served at the 1991 conference, or at any further conferences." Lori Gruen, "Dismantling Oppression: An Analysis of the Connection Between Women and Animals," at 89-90. Carol J. Adams sets out to provide a philosophical exploration of the claim that "animal rights should be practically enacted through allvegetarian conferences." Carol J. Adams, "The Feminist Traffic in Animals," at 196. Both papers are found in Ecofeminism: Women, Animals, Nature, edited by Greta Gaard, Temple University Press, 1993.

${ }^{9}$ Carol J. Adams, supra, at 196.

${ }^{10}$ Lori Gruen discusses this accusation and responses to it in "Dismantling Oppression: An Analysis of the Connection Between Women and Animals," supra, at 82.

${ }^{11}$ I mention these two, not because I wish to imply that they are the only ones possible, nor that they are even the most significant, but only that they are the approaches that one commonly finds in the literature on vegetarianism. There are, of course, many, many different versions of feminist ethics, including the increasing prominence of lesbian ethics. Thus far, most of the treatments of vegetarianism that I have come across have tended to affiliate with either an antidomination ethic or a care ethic approach.

${ }^{12}$ Donovan, supra, at 356.

${ }^{13}$ Donovan, supra, at 360.

${ }^{14}$ Noddings, supra, at 157.

${ }^{15}$ Noddings, supra, at 152.

${ }^{16}$ Nell Noddings, Caring: A Feminine Approach to Ethics and Moral Education, at 157. University of California Press, 1984.

${ }^{17}$ Noddings, supra, at 149.

${ }^{18}$ Noddings, supra, at 152.

${ }^{19}$ Noddings, supra, at 157.

${ }^{20}$ Noddings, supra, at 157 . On page 154 , she explains that part of ber criticism of utilitarianism results from its treating animals as a vast group of interchangeable entities, 
of sources of pleasure and pain. The individuals are not the focus, but rather the amounts of pleasure and pain. She is discussing the debates about the "replaceability argument."

${ }^{21}$ Noddings, supra, at 154.

${ }^{22}$ One might see echoes of utilitarianism in her discussion of pain, which borders on setting out something like a universalizing generalization, which she labors greatly to avoid elsewhere. She claims that her ethic of caring "strives consistently to capture our human intuitions and feelings," and that makes it preferable to utilitarian views of the sort provided by Singer. Needless to say, her claims about capturing intuitions would be disputed by many who may have different intuitions on these issues, utilitarians and ecofeminists and others. In other passages, she even suggests some kind of balancing or trading off when she talks about the need to seriously consider the impact on humans of abolishing farming and hunting and so on and implies that human needs could quite easily outweigh the interests of animals, such as they are. This too resembles some aspects of a utilitarian approach, particularly one that rests upon a presumption of human supremacism.

${ }^{23}$ Peter Singer, Animal Liberation, at ii. Second Edition. New York Review of Books/ Random House, 1990.

${ }^{24}$ Josephine Donovan, "Animal Rights and Feminist Theory." Signs: A Journal of Women in Culture and Society, Volume 15 (2), 1990, 350-375 at 350. Also reprinted in Adams and Donovan, eds., Women and Animals.

${ }^{25}$ Singer, supra, at ii.

${ }^{26}$ Donovan, supra, at 351

${ }^{27}$ Quoted in Donovan, supra, at 351. See Mary Midgley, Animals and Why They Matter: A Journey Amund the Species Barrier. Penguin Books, 1983.

${ }^{28}$ Donovan, supra, at 352

${ }^{29}$ Quoted in Donovan, at 356. From Jeremy Bentham, Introduction to the Principles of Morals and Legislation, 1789.

${ }^{30}$ Donovan, supra, at 374

${ }^{31}$ Of course, as I have already elaborated on in the discussion on Noddings above, simply taking an approach based on "caring" does not mean that one will automatically be driven to argue for vegetarianism. It is an interesting question, then, how to account for the differences between approaches which are based on care at some level. It is beyond the scope of this paper, however, to address the larger questions of choice of moral theory, levels of moral thinking, processes of moral reasoning and the complex dynamics of moral psychology and epistemology.
${ }^{32}$ Lori Gruen, "Dismantling Oppression: An Analysis of the Connection Between Women and Animals," at 80.

${ }^{33}$ Karen J. Warren, "The Power and Promise of Ecological Feminism," at 435. In Armstrong and Botzler, editors, Environmental Ethics: Divergence and Convergence. McGraw-Hill, 1993.

${ }^{34}$ Warren, supra, at 436.

35 Warren, supra, at 442.

${ }^{36}$ Warren, supra, at 443.

${ }^{37}$ Kathryn Paxton George, "Discrimination and Bias in the Vegan Ideal," at 19. Journal of Agricultural and Envimnmental Ethics, Volume 7(1), 1994.

${ }^{38}$ George, supra, at 23.

${ }^{39}$ Beardsworth and Keil, supra, at 289-290.

${ }^{40}$ Gary E. Varner. "In Defence of the Vegan Ideal: Rhetoric and Bias in the Nutrition Literature." Journal of Agricultural and Environmental Ethics, Volume 7(1), 1994. See also Johanna Dwyer and Franklin M. Loew. "Nutritional Risks of Vegan Diets to Women and Children: Are They Preventable?" in the same issue.

${ }^{41}$ Barbara Noske uses this term in Humans and Other Animals, Pluto Press, 1989, at 24.

${ }^{42}$ Donovan, supra, at 375.

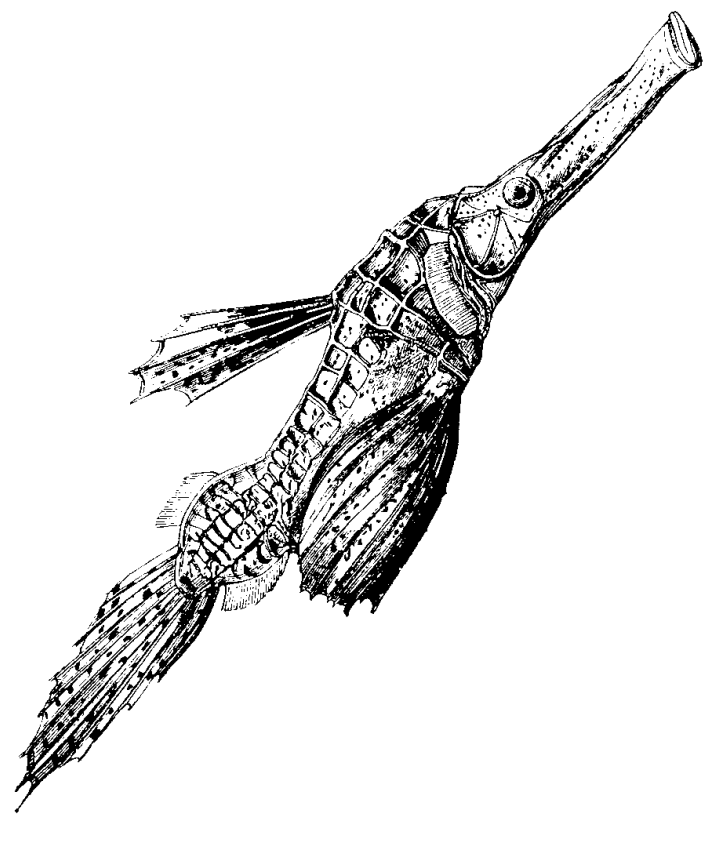




\section{Reply: \\ Feminism and Utilitarian Arguments for Vegetarianism:}

\author{
A Note on Alex Wellington's \\ "Feminist Positions on Vegetarianism"
}

\section{Nicholas Dixon Alma College}

Alex Wellington has provided an invaluable survey of feminist arguments for and against vegetarianism. My utilitarian defense of vegetarianism was intended to preclude neither rights-based nor feminist justifications. Its goal, rather, was to show that the least controversial ground for vegetarianism-one that extends moral concern to nonhumans on the basis of their ability to suffer and feel pleasure-is sufficient to respond to two well-known defenses of meat eating.

Whereas most of the feminist philosophers whom Wellington discusses reach similar conclusions to those of my utilitarian argument, or else disagree because they reject traditional utilitarian or rights-based frameworks, one of them-Kathryn Paxton George-raises an objection that is directly relevant to my utilitarian case. George argues that certain biological facts about women and ecological and economic realities about the poor and people who live in some developing countries would make the demand that they become vegetarians unfairly burdensome. If George has her empirical data right, then, as Wellington correctly observes, utilitarian advocates of vegetarianism may have to carve out wide exceptions to the demand that we all become vegetarians. Women who lack the resources to

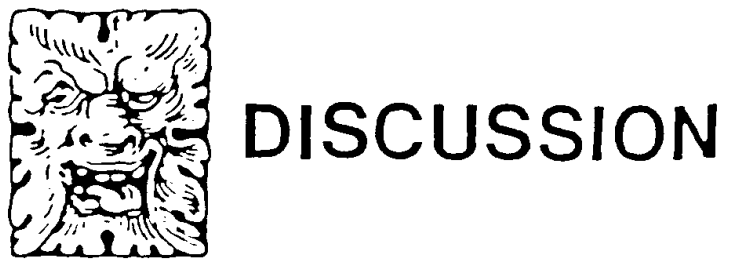

compensate for the nutritional deficit that would allegedly result from giving up meat and people, especially those in developing countries, who cannot find affordable nonmeat sources of protein would be excused if vegetarianism would cause them more suffering than is currently inflicted on the nonbuman animals that they eat.

However, contrary to Wellington's claim that such limitations on the argument for vegetarianism would be "somewhat arbitrary," they are perfectly compatible with a utilitarian approach. The most famous utilitarian vegetarian of all, Peter Singer, concedes that his argument may not apply to Eskimos, whose only available source of protein is meat. ${ }^{1}$ A consistent utilitarian must take into account all relevant consequences, and, while it may make the morality of meat eating more complex, it is not at all arbitrary to recognize crucial differences between men and women and between industrialized and developing countries. The fact that utilitarianism avoids blanket moral judgments that ignore vital distinctions between different cases is one of its great advantages as a moral theory.

A similar response applies to George's concern that the utilitarian argument for vegetarianism would brand women and inhabitants of developing countries as a "moral underclass" of people who are unable to fulfill the duty to be vegetarian. The key point is that utilitarianism would impose no such duty in the first place on any people for whom vegetarianism would be unduly burdensome, in that their sacrifices in refraining from eating meat would be greater than the harm currently caused by their meat eating. Hence neither women, poor people, nor inhabitants of developing countries would be condemned to being unable to fulfill their moral duties, and the charge that the utilitarian argument for vegetarianism serves only "the most privileged class of humans" is unfounded.

So, even if George's empirical claims are supported by the evidence, they do not undermine the utilitarian case for vegetarianism. A utilitarian can consistently relativize the duty to refrain from eating meat to those on whom it would not impose an unfair burden.

\section{Notes}

1 Peter Singer, Practical Ethics, 2nd. Edition (Cambridge: Cambridge University Press, 1993), p. 62.

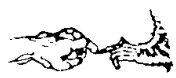

